\title{
Relationship of Conception Rate with Antral Follicle Count, Nutritional Parameters and Animal Behavior in Brahman Cows Submitted to TAI
}

\section{Relação da Taxa de Concepção com a Contagem de Folículos Antrais, Parâmetros Nutricionais e Comportamento Animal em Vacas Brahman Submetidas à IATF}

\author{
Maria Eduarda Scheel Bomtempo ${ }^{a}$; Marcela Bortoletto Cerezettia; Fábio Lucas Zito de Moraes ${ }^{\mathrm{a}}$; Renan Carlos Vicentin \\ de Campos Silva ${ }^{\mathrm{ab}}$; Elis Lorenzettiab; Fábio Morotti*ab \\ ${ }^{a}$ Universidade Estadual de Londrina, Programa de Pós-Graduação Stricto Sensu em Clínicas Veterinárias. PR, Brasil.
bUnopar. PR, Brasil. \\ *E-mail: fabiomorotti@uel.br
}

\begin{abstract}
Improving reproductive performance is important to increase farm profitability. The relationship of antral follicle count (AFC), body condition score (BCS), weight, and animal behavior on the conception rate in cows submitted to timed artificial insemination (TAI). Cows ( $\mathrm{n}=122$ ) received a conventional TAI protocol of three managements (D0, 8, and 10) based on estrogen and progesterone, in addition to monitoring estrus expression before insemination. The BCS and behavior score were assessed every day of the TAI protocol. Weight was measured at D0 and in the pregnancy diagnosis (D40), and AFC was determined at D0. For analysis, the groups were established according to AFC (low, intermediate, and high), behavior animal (calm, restless, and agitated), weight variation (gaining, maintaining, and losing), and BCS variation (gaining, maintaining, and losing). The overall conception rate was 50\%, and it was not associated with ( $\mathrm{P}>0.05)$ the $\mathrm{AFC}$ classification (low $/ 52.6 \%$, intermediate $/ 50.9 \%$, and high $/ 45.4 \%$ ), weight variations (gaining/43.0\%, maintaining $/ 54.7 \%$, and losing $/ 47.1 \%$ ), BCS variations (gaining/44.0\%, maintaining $/ 54.3 \%$, and losing/37.5\%) and animal behavior (calm/43.0\%, restless $/ 54.7 \%$, and agitated $/ 47.1 \%$ ). However, the low AFC showed a higher $(\mathrm{P}=0.05)$ proportion of animals with high intensity of estrus expression $(94.7 \%)$. In addition, a higher score for animal reactivity $(\mathrm{P}=0.001)$ was noted on the first day of the management of TAI protocol than to the other days of the hormonal protocol. The low AFC resulted in a higher proportion of cows with high estrus expression and the management practices for TAI determined a greater animals reactivity at the beginning of the breeding program.
\end{abstract}

Keywords: Body Condition. Artificial Insemination. Reproductive Performance. Live Weight.

\section{Resumo}

Melhorar o desempenho reprodutivo é importante para aumentar a lucratividade das propriedades. Assim, nós avaliamos a contagem de folículos antrais (CFA), o escore de condição corporal (ECC), o peso vivo e o comportamento animal sobre à taxa de concepção de vacas Brahman submetidas à inseminação artificial em tempo-fixo (IATF). Vacas $(n=122)$ receberam um protocolo convencional de IATF de três manejos (D0, 8 e 10) a base de estrógeno e progesterona, além do monitoramento da expressão de estro antes da inseminação. O ECC e o comportamento animal foram avaliados em todos os dias do protocolo, o peso foi mensurado no D0 e no diagnóstico de gestação (D40) e a CFA no D0. Para análise, estabeleceu-se os grupos de CFA (baixa, intermediária e alta), do comportamento (calma, inquieta e agitada), do peso (ganhando, mantendo e perdendo) e do ECC (ganhando, mantendo e perdendo). A taxa de concepção geral foi de $50 \%$, e não esteve associada ( $p>0,05)$ a classificação da CFA (baixa/52,6\%, intermediária/50,9\% e alta/45,4\%), do peso (ganhando/43,0\%, mantendo/54,7\% e perdendo/47,1\%), do ECC (ganhando/44,0\%, mantendo/54,3\% e perdendo/37,5\%) e do comportamento (calma/43,0\%, inquieta/54,7\% e agitada/47,1\%). No entanto, a baixa CFA apresentou maior $(p=0,05)$ proporção de animais com alta intensidade de estro (94,7\%) e foi observado maior escore de reatividade $(p=0,001)$ no primeiro dia de manejo da IATF em relação aos outros dias. Vacas com baixa CFA resultaram em maior proporção de expressão de estro e o primeiro dia de manejo da IATF determinou uma maior reatividade animal em relação aos outros dias do protocolo.

Palavras-chave: Condição Corporal. Inseminação Artificial. Performance Reprodutiva. Peso Vivo.

\section{Introduction}

The relationship between the antral follicle count (AFC) and reproductive performance in cattle has excelled in the world scenario, due to the significant increase of studies related to the subject, mainly correlated with the ovarian follicular population, its influence on the reproductive performance and its correlation with biotechnologies in cattle (IRELAND et al., 2011; RICO et al., 2012; SILVASANTOS et al., 2014; BATISTA et al., 2014; SANTOS et $a l ., 2016)$. Despite the research, several aspects related to the reproductive physiology are not fully understood, considering differences between subspecies (Bos taurus taurus vs. Bos taurus indicus), and characteristics related to ovarian follicular population and its influence on fertility in cattle (MOROTTI et al., 2015).

The AFC in a bovine female has considerable repeatability along consecutive evaluations (BURNS et al., 2005; IRELAND et al., 2007). Thus, based in the AFC consistency in the same individual became a strategic opportunity to the females classification into a low, intermediate or a high number of follicles, considering follicles $\geq 3 \mathrm{~mm}$ in diameter through ultrasound examination during the estrous cycle (BURNS et al., 2005; IRELAND et al., 2007, 2008; SILVASANTOS et al., 2014). 
In Bos taurus taurus females, low AFC is associated with several characteristics related to low reproductive performance, including small ovaries (IRELAND et al., 2008), a lower probability of conception at the end of the reproductive season (MOSSA et al., 2012), reduced response to superovulation treatment, lower potential for embryo production and fewer viable embryos (SINGH et al., 2004; IRELAND et al., 2007), lower circulating concentrations of progesterone and anti-Müllerian hormone (IRELAND et al., 2011; EVANS et al., 2012; JIMENEZ-KRASSEL et al., 2015), and reduction of the endometrial thickness (JIMENEZKRASSEL et al., 2009).

In contrast, animals with higher AFC have physiological and endocrine characteristics opposite to those of low AFC, suggesting a relationship between higher AFC and important aspects of reproductive fertility in Bos taurus taurus cattle (IRELAND et al., 2011; EVANS et al., 2012). Also, this situation is poorly understood in Bos taurus indicus animals due to the limited number of studies in this subspecies.

In Brazil, the first studies with Bos taurus taurus and Bos taurus indicus animal showed that donors with higher AFCs were more efficient to in vivo and in vitro embryo production, results similar to the United States and European studies (SILVA-SANTOS et al., 2014; SANTOS et al., 2016). On the other hand, recent studies (MOROTTI et al., 2018; MORAES et al., 2019) that conducted timed artificial insemination (TAI) and large numbers of Nelore females (Bos taurus indicus) have revealed that the pregnancy to TAI is $10 \%$ higher for the low AFC group compared to the high AFC female. Similarly, in dairy cattle (Bos taurus taurus), low AFC has been associated with better reproductive rates and greater productive longevity in the herd than high AFC (JIMENEZKRASSEL et al., 2017).

Considering the contradictory studies that associate AFC and pregnancy rate, as well as evidence that the AFC influence in Bos taurus indicus female is not yet fully elucidated, there is a need for greater understanding of this reproductive characteristic in Zebu cattle. Furthermore, management strategy, nutritional condition, body condition score, and productive parameters have been pointed as influence factors on reproductive performance (MARQUES et al., 2018; MORAES et al., 2019). In this context for example, a herd in which females do not have a uniform body condition score during the breeding season can lead to an increase in the number of non-pregnant cows and impair reproductive efficiency (MARQUES et al., 2018).

On the other hand, there is also a report that animal behavior can influence the reproductive performance, resulting in different conception rates of cows classified as calm or agitated temperament (FORDYCE; GODDARD; SEIFERT, 1982). However, although it also affects the reproduction, animal behavior (VON BORELL et al., 2007) has been poorly studied in association with reproductive indexes in Bos indicus cattle. Therefore, this study aimed to evaluate whether the conception rate in Brahman cows (Bos taurus indicus) submitted to the timed artificial insemination (TAI) protocol is related to the AFC, nutritional parameters, and animal behavior.

\section{Material and Methods}

\subsection{Location, animals and food management}

The experiment was conducted according to the Animal Experimentation Ethics Committee of the State University of Londrina based on Federal Law $\mathrm{N}^{\circ} 11.794$ of October 08th, 2008. The study was conducted from December 2018 to January 2019, in a farm located in the municipality of Ariranha do Ivaí, Paraná, Brazil, with latitude: $24^{\circ} 23$ '11 "S and longitude: $51^{\circ} 35^{\prime} 07^{\prime}$ " W. According to the KöppenGeiger classification (PEEL; FINLAYSON; McMAHON, 2007) the climate is tropical with a dry winter, with temperatures averaging $21.8^{\circ} \mathrm{C}$ and an average annual rainfall of approximately $1500 \mathrm{~mm}$.

For this study, Brahman cows (Bos taurus indicus; $\mathrm{n}=$ 122 ), aged between 24 and 96 months, with 45 to 60 days postpartum, body condition score (BCS) ranging from 2.5 to 3.0 (scale 1-5; LOWMAN; SCOTT; SOMERVILLE, 1976) and live weight between 300 and $560 \mathrm{~kg}$ were selected. All the animals in this study received a uniform and adequate nutritional management, being fed to pasture (Brachiaria brizantha) and receiving mineral salt and water ad libitum.

On a random day of the estrous cycle (D0), all females received an ovulation synchronization protocol to timed artificial insemination (TAI). On the same day (D0), AFC, weight, BCS, and trunk reactivity score were determined as shown in Figure 1.

\subsection{Hormonal protocol for TAI and study design}

Hormonal treatment for ovulation synchronization was performed on a random day of the estrous cycle (D0) from the insertion of an intravaginal device containing 1.2 g progesterone (P4, FertilCare ${ }^{\circledR} 1200$, Vallée, Brazil) in combination with the application of $2 \mathrm{mg}$ estradiol benzoate (EB; RIQ-BE®, Agener União, Brazil) intramuscularly (IM). After 8 days (D8), P4 devices were removed, followed by IM administration of $500 \mu \mathrm{g}$ of sodium cloprostenol (PGF2 $\alpha$; Estron ${ }^{\circledR}$, Agener União, Brazil), 300 IU of equine chorionic gonadotropin (eCG; Folligon $\AA$, MSD Animal Health, Sao Paulo, Brazil) and $1 \mathrm{mg}$ of estradiol cypionate (EC; Fertilcare ${ }^{\circledR}$ Ovulation, Vallée, Sao Paulo, Brazil). TAI was performed 48 hours later (D10) by a single technician.

The inseminations were performed with frozen semen from Aberdeen Angus bull thawed at $36{ }^{\circ} \mathrm{C}$ for 30 seconds (Semen and Embryo Defrost - WTA ${ }^{\circledR}$, WTA, Cravinhos, SP, Brazil), which follows the quality standards established by the Brazilian College of Animal Reproduction (CBRA, 2013). 
Figure 1 - Description of the ovulation synchronization protocol used to evaluate the relation of antral follicle count (AFC), body condition score (BCS), weight, and animal behavior on the conception rate in Brahman cows submitted to timed artificial insemination (TAI). P4 - progesterone, EB - estradiol benzoate, PGF $2 \alpha$ - sodium cloprostenol, eCG - equine chorionic gonadotrophin, EC - estradiol cypionate

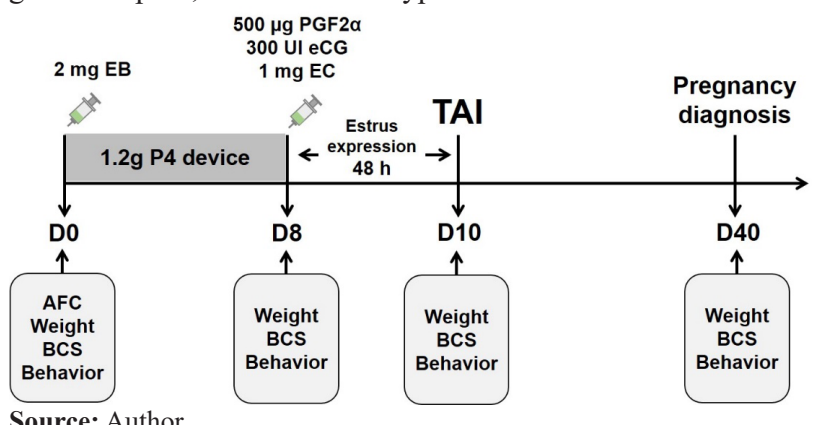

Source: Author.

On Day 8 of the protocol (D8), immediately after hormonal application all the females were marked with a red stick (AllWeather ${ }^{\circledR}$, Paint Stick, USA) in the sacrococcygeal region to determine the estrus expression on the day of insemination (D10). The estrus expression was performed visually by the same technician in all the animals, being classified according to the proportion of paint removed: no estrus expression - no or low paint removal, low estrus expression - partial paint removal $(<75 \%)$, and high estrus expression - near-complete $(>75 \%)$ or complete removal of paint (NOGUEIRA et al., 2019).

\subsection{Antral follicle count}

AFC was established on D0 (beginning of the TAI protocol) by a transrectal ultrasound examination (Sono Scape ${ }^{\circledR}$, Shenzhen, China, model A5V) equipped with a 5 $\mathrm{MHz}$ linear transducer. To determine AFC, the pair of ovaries (right and left) were assessed from one face to the other starting at the ovarian pedicle and the total number of antral follicles (follicles $\geq 3 \mathrm{~mm}$ in diameter) were counted as proposed by Burns et al. (2005) and Morotti et al. (2018).

\subsection{Assessment of weight and body condition score}

In this study each animal was evaluated without prior fasting and random entry was respected in the containment trunk. The live weight was measured at the beginning of the TAI protocol (D0) and later on the day of pregnancy diagnosis (D40), using a digital scale (TRU-TEST, ID 3000) coupled to the containment trunk itself. The BCS evaluation was performed considering the visual and tactile evaluation in (D0) and (D40) by the same evaluator. The rating scale was based on Lowman's methodology; Scott; Somerville (1976), ranging from 1 to 5 (1 - cachectic and 5 - obese) and considering tissue reserves, with emphasis on fat and muscle coverage, associated with specific anatomical regions such as ribs, spinous and transverse spine processes vertebral, paralumbar fossa, lumbar vertebrae, iliac tuberosity, the base of the tail and sacrum bone.

\subsection{Reactivity score evaluation}

The animal reactivity behavior was evaluated during the female stay in the containment trunk, on days of TAI protocol management, named (Days 0, 8, 10, and 40). Reactivity assessments were based on the study by Grandin (1993) as (Table 1).

Table 1 - Movement scores used to determine animal behavior in the containment trunk

\begin{tabular}{|c|l|}
\hline SCORES & Reactions in the containment trunk \\
\hline $\mathbf{1}$ & Quiet, without any movement \\
\hline $\mathbf{2}$ & Restless, little movement \\
\hline $\mathbf{3}$ & Restless, frequent movements \\
\hline $\mathbf{4}$ & $\begin{array}{l}\text { Very restless, tremors, constant and vigorous } \\
\text { movements }\end{array}$ \\
\hline $\mathbf{5}$ & Violent, constant and vigorous movements \\
\hline
\end{tabular}

\subsection{Pregnancy diagnosis}

The cows were evaluated by transrectal ultrasound 30 days after TAI (D40), and pregnancy was confirmed only in those females in which the embryonic vesicle was identified, and the embryo was viable by monitoring the heartbeat. The conception rate was analyzed by the ratio from total of pregnant cows by total of inseminated cows.

\subsection{Statistical analysis}

For statistical analysis, the first quartile $(\mathrm{Q} 1=15$ follicles $)$, the median (M2 = 20 follicles), and the third quartile (Q3 = 30 follicles) were extracted from the antral follicle population of the cows included in the study $(\mathrm{N}=122)$. Subsequently for data analysis, experimental groups were defined as low (Q1 $\leq 15$ follicles), intermediate (cows with $\mathrm{AFC} \geq 16$ and $\leq$ 29 follicles), and high count (Q3 $\geq 30$ follicles). To classify the cows according to the animal behavior (reactivity score evaluation), the average movement score of each cow was considered in each management day, so that an average of each female $=1.0$ was considered calm, $>1.0$ and $\leq 2.0$ was considered restless and $\geq 2.1$ was considered agitated. Variations of weight and BCS between days 0 and 40 determined groups: gaining (positive variation from +10 to $+40 \mathrm{~kg}$ ), maintaining (variation from -9 to $+9 \mathrm{~kg}$ ) or losing weight (negative variation from -10 to $-40 \mathrm{~kg}$ ), as well as gaining (positive change from +0.25 to +0.75 points), maintaining (variation from -0.25 to +0.25 points) or losing $\mathrm{BCS}$ (negative variation from -0.25 to -0.75 points).

The effect of AFC groups on the studied variables was analyzed by the generalized linear model (GLM), including the main effect of AFC as a fixed factor and all other sources of variation were included as the model covariates. In the presence of a significant effect, the means were compared by the Tukey test. Temporal variables were analyzed by repeated measures using the GLM with random effect. Conception rates were analyzed by the binary logistic regression model including as a fixed effect the AFC groups, animal behavior 
classification, and weight and BCS variations. The rate of estrus expression was analyzed by Fisher's exact test.

For descriptive analysis, quantitative data are presented as mean (M) and standard deviation (SD) and qualitative data as percentage (\%). All the statistical analyzes were performed using the Minitab ${ }^{\circledR}$ statistical software version 18.1. The significance level for rejecting $\mathrm{H} 0$ (the null hypothesis) was $5 \%$, so a significance level $\leq 0.05$ was considered to indicate an effect of categorical variables and their interactions. For statistical tendency, $\mathrm{P}>0.05$ and $<0.1$ was considered.

\section{Results and Discussion}

In the present study, the conception rate of Brahman cows submitted to the TAI protocol was 50\% (61/122) and the AFC, nutritional status, and behavior animal (reactivity score) did not determine the significant effect $(\mathrm{P}>0.05)$ on conception rate (Figure 2). However, there was no significant effectobserving a numerical advantage of $7 \%$ percentage points for the group with low (52.6\%) compared to high AFC (45.5\%; Figure 2A).

Figure 2 - Conception rate of Brahman cows (Bos taurus indicus) submitted to ovulation synchronization protocol for timed artificial insemination (TAI) according to antral follicle count classification (AFC; A), variations of weight (B) and body condition score (BCS; C) between days 0 and 40, and the animal behavior (reactivity) in the containment trunk (D)
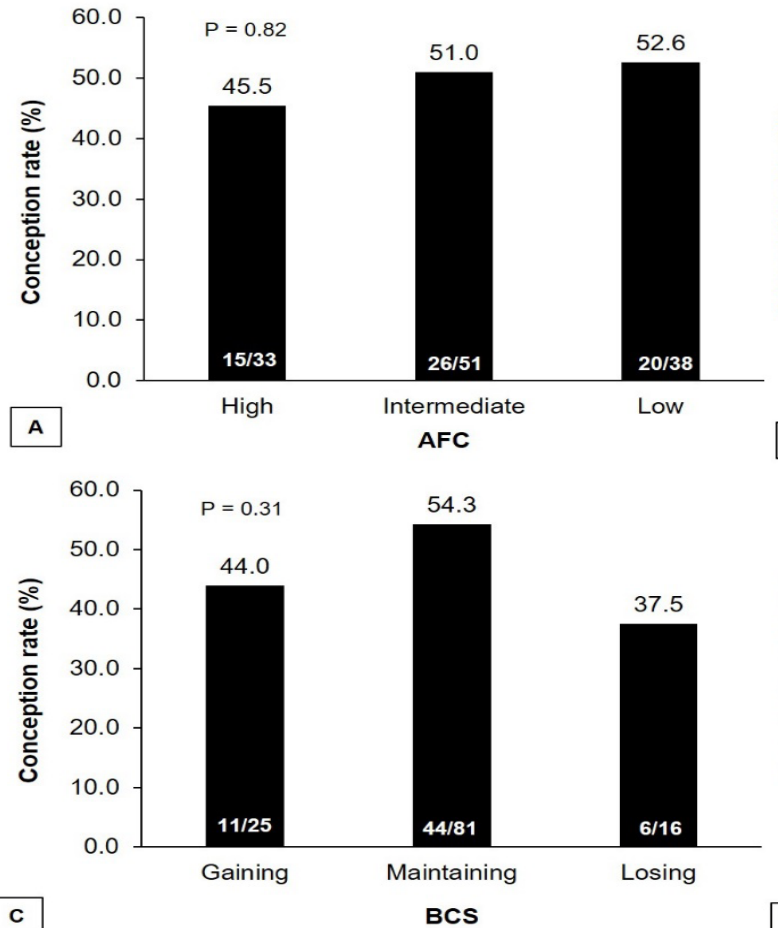

Source: Author

Considering the estrus expression at the TAI moment (D10), the group with low AFC presented the highest $(\mathrm{P}=$

Figure 3 - Estrus expression rate in Brahman cows (Bos taurus indicus) with different antral follicle count (AFC; low, intermediate and high), after performing the ovulation synchronization protocol for timed artificial insemination (TAI). Lowercase letters $(\mathrm{a}, \mathrm{b})$ indicate difference $(\mathrm{P} \leq 0.05)$ among AFC groups (low, intermediate, and high) for high expression estrus

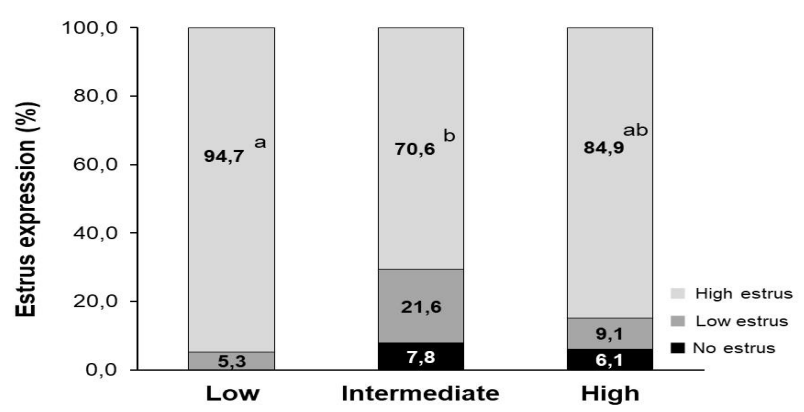

Source: Author.
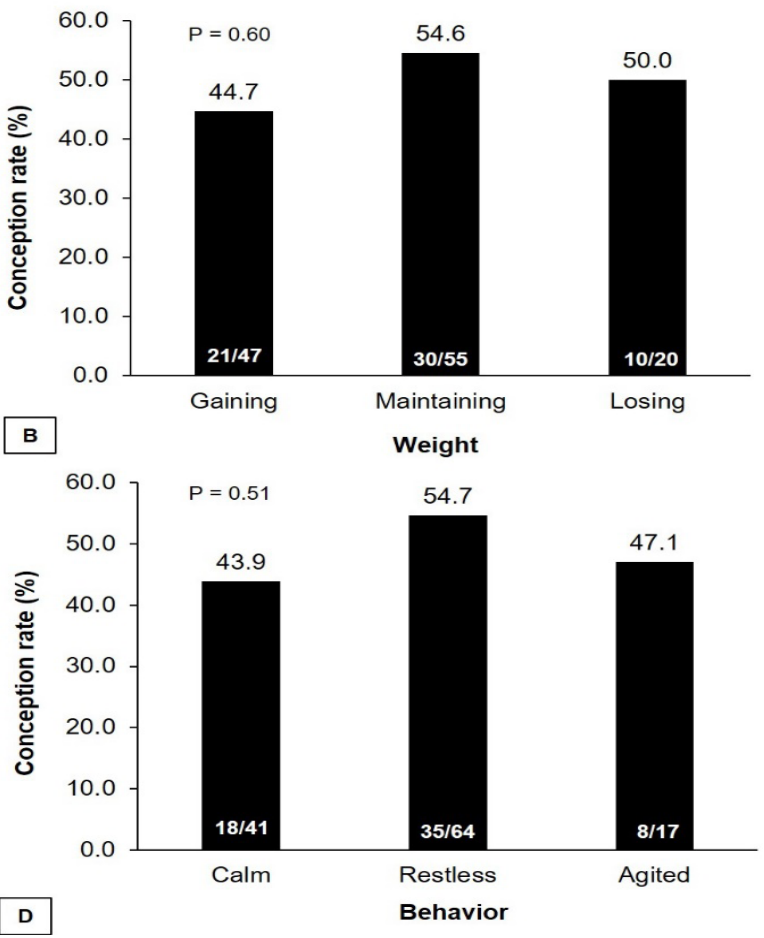

0.05) proportion of cows with high estrus expression (94.7\%), compared with intermediate and high AFC groups.

There was no variation $(\mathrm{P}>0.05)$ for the BCS and live weight during the reproductive program for TAI. However, the animal behavior showed a higher animal reactivity $(\mathrm{P}=$ 0.001 ) at the beginning of the TAI protocol compared to the other moments (Figure 4). On the other hand, after the final analysis of the individual movement score throughout the TAI management practices, a higher proportion of cows ( $\mathrm{P}$ $<0.05$ ) was classified as calm compared to restless or very restless. Movement scores 1 and 2 were the most common during management practices, and a low proportion of cows received scores 3 and 4 (Figure 6). Score 5 was not found in any animal. 
Figure 4 - Average of movement score in the trunk (animal behavior/reactivity) from Brahman cows (Bos taurus indicus) along timed artificial insemination (TAI) management practices. Lowercase letters $(\mathrm{a}, \mathrm{b})$ indicate difference $(\mathrm{P}<0.05)$ among evaluation days during TAI protocol

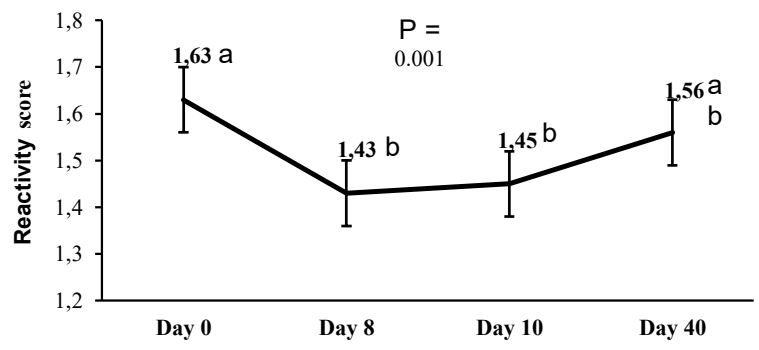

Source: Author.

Figure 5 - Frequency of distribution of movement scores in the containment trunk (animal behavior) in Brahman cows (Bos taurus indicus) submitted to management practices for timed artificial insemination (TAI)

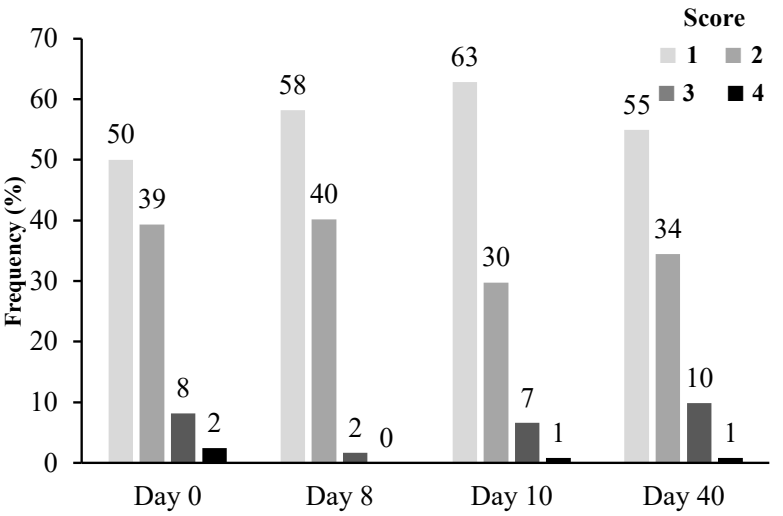

Source: Author.

This is the first study that evaluated the relation among $\mathrm{AFC}$, animal behavior, and nutritional status (BCS and body weight) with fertility in Brahman cattle females submitted to TAI. Although these evaluations did not substantially influence the conception rate of the present study, it was possible to identify a high estrus expression in females with low AFC, as well as it was evident that the first management in the TAI protocol seems to be more stressful for the herd, as demonstrated in the results of animal behavior. However, in subsequent management, females showed adapted to reproductive practices. This issue is highly relevant for herd management, especially in Brazil, where there is a predominance of Bos taurus indicus animals and that about 13 million matrices received a TAI protocol during the breeding season (BARUSELLI et al., 2019). In addition, issues involving animal welfare are increasingly gaining prominence in the livestock scene as they directly impact the production systems efficiency in beef and dairy cattle (VON BORELL et al., 2007; RITTER et al., 2019).

In the present study, the AFC classification used in Brahman females was very close to the AFC classification used by Santos et al. (2016) in Nelore cattle which established low AFC ( $\leq 10$ follicles), intermediate ( 11 to 24 follicles) and high ( $\geq 25$ follicles). In this study the authors also reported a conception almost 7 percentual points higher in cows with low AFC compared to the high AFC group. Although the low number of animals in the present study may compromise an accurate assessment of conception rate according to AFC categories, the controversial aspects of the results in Bos taurus indicus compared to Bos taurus taurus animals are remarkable.

For example, several studies conducted with taurine animals (Bos taurus taurus) have associated low AFC with poor reproductive performance, including many other negative factors related to fertility, including lower conception rates, smaller ovaries, lower responsiveness to superovulation treatments and low concentrations and circulating progesterone and anti-müllerian hormone (IRELAND et al., 2007; 2008; JIMENEZ-KRASSEL et al., 2009; IRELAND et al., 2011; EVANS et al., 2012; MOSSA et al., 2012; MARTINEZ et al., 2016).

The study conducted by Morotti et al. (2018) suggested a possible relationship among $\mathrm{AFC}$, follicular diameter, and conception rate in Nelore cows, although showed no relationship with corpus luteum (CL) diameter and progesterone concentration. These authors revealed that follicular diameters, during hormonal treatment for TAI, were higher for cows with low $\mathrm{AFC}$ ( $\leq 15$ follicles) from the emergency until the time of ovulation, justifying a higher pregnancy in the low AFC group, (61.7\%) versus (49.5\%) high AFC cows ( $\geq 45$ follicles). Other studies conducted by Santos et al. (2016) and Moraes (2019) in Nelore cattle subjected to TAI also showed that high AFC cows did not exhibit a higher conception rate compared to low count as demonstrated in taurine herd from the United States and Europe. These studies demonstrate very controversial data when pregnancy is evaluated considering the different AFC in Bos taurus taurus and Bos taurus indicus herd (CUSHMAN et al., 2009; EVANS et al., 2012; MOSSA et al. , 2012; SANTOS et al., 2016; MOROTTI et al., 2018), making the subject quite challenging and worthy of further investigation.

Although variations in BCS did not influence the conception rate, numerically cows that maintained BCS between days 0 and 40 demonstrated a conception rate $10 \%$ higher when compared to cows that gained or lost BCS (54.3 vs. 44.0 and $37.5 \%$, respectively). There was no difference between the groups to weight variations, being found only slight variations in the conception rate among animals that gained (44.7\%), maintained (54.6\%), or lost weight (50.0\%).

In the present study, there was an expectation that cows classified as gaining or maintaining weight and/or BCS would have a better reproductive performance, as well as a lower performance could be expected for those animals that were losing weight and/or BCS, considering the great influence that nutritional aspects have on the cattle reproduction. However, our hypothesis was not reached, perhaps due to the lower condition of the challenges suffered (small variations 
in weight and BCS) and the limited number of animals used in this study. Particularly the property on which of this study was conducted is a commercial farm, with good animal management practices, nutritional planning, which certainly minimizes the occurrence of challenges. Therefore, it is important to repeat this investigation under more challenging conditions and in large herds.

There was also no difference in the conception rate according to animal behavior. However, the results showed variations that can reach up to $10 \%$ among cows classified as restless (54.6\%) and those classified as calm (43.9\%). These results were contradictory to other studies that observed a relationship between behavior and fertility in cows, showing that calmer animals had better conception rates when compared to more agitated behavior cows (FORDYCE; GODDARD; SEIFERT, 1982). In addition, Burrow, Seifert, and Corbet (1988) demonstrated that bovine females that had a higher trunk exit speed had a lower number of noticeable estrus when compared to those that showed calmer behaviors.

It was believed that the results of this study would confirm a possible relationship among AFC, BCS, live weight, and reactivity behavior on the trunk with the conception rate, but no variations were observed. However, it was evident that through the evaluation of estrus expression, females with low AFC (94.7\%) were the ones that best presented such behavior, demonstrating the importance of associating such evaluations with fertility characteristics. The AFC assessments associated with nutritional parameters (BCS and live weight) and animal behavior characteristics (reactivity to the trunk) in TAI protocol present complementary and low-cost tools that add greater knowledge to the herd, highlighting the nutritional needs of each animal and strategies management to improve the property's productivity index.

This study is presented as an original investigation in Brahman breed (Bos taurus indicus), in which a possible relationship was investigated among AFC, nutritional parameters, and animal behavior with conception rate to TAI. In addition, it was identified that the first management of the TAI protocol represents the situation of the highest level of stress to the animals, probably due to the first contact with the practices of hormonal protocol management. However, the management practices followed are similar and the herd showed a calmer behavior until pregnancy diagnosis.

\section{Conclusion}

The low AFC resulted in a higher proportion of cows with high expression estrus and the first day of management for TAI determined a greater reactivity for the animals compared to the other days of the protocol. It is highlighted herein the importance of carrying out the AFC evaluation in Brahman females as a strategy indicative of fertility due to the high estrus expression in females with low AFC. Finally, new studies with a larger number of animals should still be considered, especially in animals of the Brahman breed which are still little explored in the literature.

\section{References}

BARUSELLI, P.S. et al. Evolução e perspectivas da inseminação artificial em bovinos. Rev. Bras. Reprod. Anim., v.43, n.2, p.308314, 2019.

BATISTA, E.O. et al. Plasma antimullerian hormone as a predictor of ovarian antral follicular population in Bos indicus (Nelore) and Bos taurus (Holstein) heifers. Reprod. Domest. Anim., v.49, n.3, p.448-452, 2014. doi: 10.1111/rda.12304

BURNS, D.S. et al. Numbers of antral follicles during follicular waves in cattle: evidence for high variation among animals, very high repeatability in individuals, and an inverse association with serum follicle-stimulating hormone concentrations. Reprod. Biol., v.73, n.1, p.54-62, 2005. doi: 10.1095/biolreprod.104.036277.

BURROW, H. M.; SEIFERT, G. W.; CORBET, N. J. A new technique for measuring temperament in cattle. In: PROCEEDINGS OF THE AUSTRALIAN SOCIETY OF ANIMAL PRODUCTION, may 1988, Sydney. Proceedings [...]. Sydney: ASAP, 1988. p. 154-157.

CBRA - Colégio Brasileiro De Reprodução Animal. Manual para exame andrológico e avaliação de sêmen animal. Horizonte: CBRA, 2013.

CUSHMAN, R.A. et al. Evaluation of antral follicle count and ovarian morphology in crossbred beef cows: investigation of influence of stage of the estrous cycle, age, and birth weight. $J$. Anim. Sci., v. 87, n. 6, p. 1971-1980, 2009. doi: 10.2527/jas.20081728.

EVANS, A.C.O. et al. Effects of maternal environment during gestation on ovarian folliculogenesis and consequences for fertility in bovine offspring. Reprod. Domest. Anim., v.47, n.4, p.31-37, 2012. doi: 10.1111/j.1439-0531.2012.02052.x.

FORDYCE, G.; GODDARD, M.; SEIFERT, G. W. The measurement of temperament in cattle and effect of experience and genotype. Anim. Prod., v. 14, p. 329- 332, 1982.

GRANDIN, T. Behavioral agitation during handling of cattle is persistent over time. Appl Anim Behav Sci, v.36, n.1, p.1-9, 1993.

IRELAND, J. J. et al. Does size matter in females? An overview of the impact of the high variation in the ovarian reserve on ovarian function and fertility, utility of anti-Müllerian hormone as a diagnostic marker for fertility and causes of variation in the ovarian reserve in cattle. Reprod. Fertil. Dev., v.23, n.1, p.1-14, 2011. doi: 10.1071/RD10226.

IRELAND, J. J. et al. Follicle numbers are highly repeatable within individual animals but are inversely correlated with FSH concentrations and the proportion of good quality embryos after ovarian stimulation in cattle. Hum. Reprod, v.22, n.6, p.16871695, 2007. doi: 10.1093/humrep/dem071.

IRELAND, J. L. H. et al. Antral follicle count reliably predicts number of morphologically healthy oocytes and follicles in ovaries of young adult cattle. Biol. Reprod, v. 79, n. 6, p. 12191225, 2008. doi: 10.1095/biolreprod.108.071670.

JIMENEZ-KRASSEL, F. et al. Evidence that high variation in ovarian reserves of healthy young adults has a negative impact on the corpus luteum and endometrium during estrous cycles in cattle. Biol. Reprod, v.80, n.6, p.1272-1281, 2009. doi: 10.1095/ biolreprod.108.075093.

JIMENEZ-KRASSEL, F. Concentration of antiMüllerian hormone in dairy heifers is positively associated with productive herd life. J. Dairy Sci., v.98, n.5, p.3036-3045, 2015. doi: 10.3168/ jds.2014-8130. 
JIMENEZ-KRASSEL, F. et al. A single ultrasound determination of $\geq 25$ follicles $\geq 3 \mathrm{~mm}$ in diameter in dairy heifers is predictive of a reduced productive herd life. J. Dairy Sci. v.100, p. 5019-5027, 2017. doi: $10.3168 / \mathrm{jds} .2016-12277$.

LOWMAN, B.G.; SCOTT, N.A.; SOMERVILLE, S.H. Condition scoring of cattle. Edinburgh: Edinburgh School of Agriculture, 1976.

MARQUES, M.O. et al. Intensified use of TAI and sexed semen on commercial farms. Anim. Reprod, v.15, n.3, p.197-203, 2018. doi: 10.21451/1984-3143-AR2018-0070.

MARTINEZ, M. F. et al. Association between antral follicle count and reproductive measures in New Zealand lactating dairy cows maintained in a pasture-based production system. Theriogenology, v.85, n.3, p.466-475, 2016. doi: 10.1016/j. theriogenology.2015.09.026.

MORAES, F.L.Z. et al. Relationships between antral follicle count, body condition, and pregnancy rates after timed-AI in Bos indicus cattle. Theriogenology, v.136, p.10-14, 2019. doi: 10.1016/j.theriogenology.2019.06.024.

MOROTTI, F. et al. Is the number of antral follicles an interesting selection criterium for fertility in cattle? Anim. Reprod. Sci., v. 12, n. 3, p. 479-486, 2015.

MOROTTI, F. et al. Ovarian follicular dynamics and conception rate in Bos indicus cows with different antral follicle counts subjected to timed artificial insemination. Anim. Reprod. Sci., v.188, p.170-177, 2018. doi: 10.1016/j.anireprosci.2017.12.001.

MOSSA, F. et al. Low numbers of ovarian follicles $\geq 3 \mathrm{~mm}$ in diameter are associated with low fertility in dairy cows. J. Dairy Sci., v.95, n.5, p.2355-2361, 2012. doi: 10.3168/jds.2011-4325.
NOGUEIRA, E. et al. Timed artificial insemination plus heat I: effect of estrus expression scores on pregnancy of cows subjected to progesterone-estradiol-based protocols. Animal, v.13, n.10, p.2305-2312, 2019.doi: 10.1017/S1751731119000442.

PEEL, M.C.; FINLAYSON, B.L.; MCMAHON, T.A. Updated world map of the KöppenGeiger climate classification. Hydrol. Earth Syst. Sci. Discuss., v.11, n.5, p.1633-1644, 2007. doi: 10.5194/hess-11-1633-2007.

RICO, C. et al. Determination of anti Müllerian hormone concentrations in blood as a tool to select Holstein donor cows for embryo production: from the laboratory to the farm. Reprod. Fertil. Dev, v.24, n.7, p.932-944, 2012. doi: 10.1071/RD11290.

RITTER, et al. The complex relationship between welfare and reproduction in cattle. Reprod. Domest. Anim., v. 54, Suppl 3, p. 29-37, 2019. doi: 10.1111/rda.13464.

SANTOS, G. M. G. et al. High numbers of antral follicles are positively associated with in vitro embryo production but not the conception rate for FTAI in Nelore cattle. Anim. Reprod. Sci., v.165, p. 17-21, 2016. doi: 10.1016/j.anireprosci.2015.11.024.

SILVA-SANTOS, K. C. et al. Antral follicle populations and embryo production - in vitro and in vivo - of Bos indicus-taurus donors from weaning to yearling ages. Reprod. Domest. Anim., v. 49, n. 2, p. 228-232, 2014. doi: 10.1111/rda.12255.

SINGH, J. et al. A simple ultrasound test to predict the superstimulatory response in cattle. Theriogenology, v. 62, n.12, p. 227-243, 2004. doi: 10.1016/j.theriogenology.2003.09.020.

VON BORELL, E. et al. Stress, behaviour and reproductive performance in female cattle and pigs. Horm Behav. v.52, n.1, p.130-138, 2007. doi: 10.1016/j.yhbeh.2007.03.014. 